\title{
ANALISIS PENGARUH SUMBER PENDAPATAN DAERAH TERHADAP BELANJA MODAL DAN PENGARUH BELANJA MODAL TERHADAP BELANJA PEMELIHARAAN DALAM REALISASI ANGGARAN PEMERINTAH KABUPATEN/KOTA DI PROVINSI JAWA TENGAH DAN PROVINSI DAERAH ISTIMEWA YOGYAKARTA TAHUN 2006-2010
}

\author{
Kurniawati Nursepti Ariyani \\ Rohmad Yuliantoro
}

\begin{abstract}
The allocation of capital expenditure especially on infrastructure expenditure on local financial budget, is very important, because it can increasing public service. The increase of public service will also increase the own revenues. The increase of own revenues will endorse the economic productivity. Local government also needs transfer fund from the central government, for development. It means that capital expenditure is depends on own revenues and transfer fund.

Capital expenditure partially used to funding maintenance expenditure. It means the policy of local government on the spending of capital expenditure will effects on maintenance expenditure. This research aimed to see the effect of resource of revenues that consist of own revemues and transfer find to capital expenditure, and the effect of capital expenditure to maintenance expenditure in regions/municipals in Central java and Yogyakarta province.

The result shows that own revenue is effecting the capital expenditure, but transfer fund is not effected by the capital expenditure, the capital expenditure is effecting the maintenance expenditure.
\end{abstract}

Key word: own revenues, transfer fund, capital expenditure, maintenances expenditure.

\section{LATAR BELAKANG}

Berbagai ketimpangan antar-daerah dan pembagian sumber daya alam yang tidak tepat sasaran di masa sentralisasi menyebabkan banyaknya masyarakat yang tidak puas dengan sistem pemerintahan tersebut. Beberapa persoalan ekonomi politik yang menonjol, antara lain hubungan keuangan pusat-daerah, arus sumber daya ke luar (resource outflows) yang berlebihan dari daerah ke pusat dan dari suatu daerah ke daerah lainnya, arus dana ke luar (financial outflows) dari daerah ke pusat dan dari suatu daerah ke daerah lainnya, serta distribusi investasi dan nilai tambah industri yang sangat tidak merata. Persoalan-persoalan tersebut membuat banyaknya tuntutan rakyat untuk mengubah sistem pemerintahan yang terpusat menjadi sistem pemerintahan yang lebih bebas dan demokrasi sehingga masyarakat lebih bebas untuk mengelola sumber dayanya dan mengatur pemerintahan daerahnya sendiri.

Pelaksanaan otonomi daerah di Indonesia didasari oleh UU No. 22 Tahun 1999 tentang Pemerintah Daerah, yang direvisi dalam UU No. 32 Tahun 2004 yang Jurnal Reksa Vol.I No.1 Februari 2012 
menjelaskan lebih jauh bagaimana pengaplikasian hal-hal tersebut melalui Peraturan Pemerintah (PP), yang kemudian dipandu dengan Keputusan Menteri Dalam Negeri (Kepmendagri) No. 29 Tahun 2002 dan Peraturan Menteri Dalam Negeri (Permendagri) No. 13 Tahun 2006.

Kebijakan pemerintah Indonesia tentang otonomi daerah, yang mulai dilaksanakan secara efektif tanggal 1 Januari 2001, merupakan kebijakan yang dipandang sangat demokratis dan memenuhi aspek desentralisasi pemerintah yang sesungguhnya. Pada pelaksanaan otonomi daerah, anggaran bersifat sangat penting karena pemerintah daerah menggunakan anggaran sebagai dasar untuk mengestimasi pendapatan yang diterima dan perkiraan pengeluaran yang dilakukan pemerintah untuk menjalankan pemerintahan.

UU No. 33 Tahun 2004 menjelaskan anggaran untuk pemerintah daerah di Indonesia yang disebut Anggaran Pendapatan dan Belanja Daerah (APBD). Pemerintah daerah berhak mendapatkan sumber pendapatan lain selain pendapatan asli daerah, yaitu dana transfer dari pemerintah pusat berupa dana perimbangan. Dalam pengalokasian pendapatan asli daerah dan dana transfer pemerintah pusat, pemerintah daerah diharapkan mampu mengalokasikan anggarannya untuk mencapai kesejahteraan masyarakat dan pelayanan publik yang baik. Untuk mencapai tujuan tersebut, diperlukan perubahan alokasi anggaran dari belanja rutin ke belanja modal yang lebih banyak. Alokasi belanja modal yang lebih besar untuk infrastruktur diharapkan dapat meningkatkan pelayanan publik yang akan berpengaruh pada peningkatan minat investasi pada suatu daerah.

Aset yang bersumber dari pelaksanaan APBD merupakan output/outcome dari terealisasinya belanja modal dalam satu tahun anggaran. Dalam prakteknya belanja modal berpengaruh terhadap belanja pemeliharaan, hal ini dapat dilihat dari persentase belanja barang dan belanja pemeliharaan di suatu daerah dapat menjadi indikator bertambahnya aset pemerintah daerah serta dapat meningkatkan kepedulian akan pemeliharaan aset yang telah ada. Bila pemerintah kabupaten/kota ingin menambah aset tetap, maka pemerintah kabupaten/kota tersebut harus memperhitungkan besarnya realisasi belanja pemeliharaan agar terdapat keseimbangan antara belanja modal dan belanja untuk memelihara aset tersebut.

Berdasarkan uraian yang telah dijelaskan di atas, maka penulis ingin mengetahui seberapa besar pengaruh sumber pendapatan daerah berupa pendapatan asli daerah dan dana perimbangan terhadap belanja modal dan pengaruh belanja modal terhadap belanja pemeliharaan dalam realisasi anggaran pemerintah daerah. Obyek dalam penelitian ini adalah APBD Kabupaten/Kota di Propinsi Jawa Tengah dan Daerah Istimewa Yogyakarta periode 2006-2010 


\section{TINJAUAN PUSTAKA}

\section{Pemerintah Daerah}

Pemerintah daerah dapat dikatakan sebagai kepanjangan tangan dari pemerintah pusat yang mulai tahun 2001 sudah mempunyai hak dan kewenangan untuk mengatur dan mengelola daerahnya atau yang dikenal dengan istilah otonomi daerah. Undangundang yang memayungi tentang otonomi daerah adalah UU No. 32 Tahun 2004 tentang Pemerintah Daerah dan UU No. 33 Tahun 2004 tentang Perimbangan Keuangan antara Pemerintah Pusat dan Pemerintah Daerah.

UU No. 32 Tahun 2004 tentang Pemerintah Daerah adalah salah satu landasan yuridis bagi pengembangan otonomi daerah di Indonesia. UU No. 33 Tahun 2004 tentang Perimbangan Keuangan antara Pemerintah Pusat dan Pemerintah Daerah dimaksudkan untuk mendukung pendanaan atas penyerahan urusan pemerintah pusat kepada pemerintah daerah.

\section{Anggaran Pendapatan dan Belanja Daerah (APBD) Pengertian dan Struktur APBD}

Menurut UU No. 33 Tahun 2004 tentang Perimbangan Keuangan antara Pemerintah Pusat dan Pemerintah Daerah, APBD adalah suatu rencana keuangan tahunan daerah yang ditetapkan berdasarkan peraturan daerah tentang Anggaran Pendapatan dan Belanja Negara.

Struktur APBD yng terbaru adalah berdasarkan Permendagri No. 13 Tahun 2006 tentang Pedoman Pengelolaan Keuangan Daerah. Bentuk dan susunan APBD yang didasarkan pada Permendagri No. 13 Tahun 2006 Pasal 22 ayat (1) terdiri atas 3 bagian, yaitu: (a) pendapatan daerah, (b) belanja daerah, dan (c) pembiayaan daerah.

\section{Laporan Realisasi APBD}

Laporan realisasi anggaran adalah pengungkapan kegiatan keuangan pemerintah daerah yang menunjukkan ketaatan terhadap APBD. Di samping itu, laporan realisasi anggaran juga menyajikan ikhtisar sumber, alokasi, dan penggunaan sumber daya ekonomi yang dikelola oleh pemerintah daerah dalam satu periode pelaporan (KSAP, 2005:54).

\section{Pendapatan Asli Daerah (PAD)}

\section{Pengertian Pendapatan Asli Daerah}

Pendapatan asli daerah sebagaimana dimaksud dalam UU No. 25 Tahun 1999 Pasal 3 huruf (a) tentang Perimbangan Keuangan antara Pemerintah Pusat dan Pemerintah Daerah menjelaskan bahwa yang dimaksud dengan pendapatan asli daerah adalah penerimaan yang diperoleh dari sumber-sumber di dalam daerahnya sendiri yang dipungut berdasarkan peraturan daerah sesuai dengan peraturan perundang-undangan yang berlaku. 


\section{Klasifikasi Pendapatan Asli Daerah}

Menurut Halim (2004:67), pendapatan asli daerah berasal dari:

1) Hasil pajak daerah

2) Hasil retribusi daerah

3) Hasil perusahaan milik daerah dan hasil pengelolaan kekayaan daerah yang dipisahkan

4) Lain-lain PAD yang sah

\section{Dana Perimbangan}

Dalam UU No. 33 Tahun 2004 disebutkan dana perimbangan adalah dana yang bersumber dari pendapatan APBN yang dialokasikan kepada pemerintah daerah untuk mendanai kebutuhan daerah dalam rangka pelaksanaan desentralisasi. Dana perimbangan yang diperoleh pemerintah daerah, terdiri dari dana alokasi umum (DAU), dana alokasi khusus (DAK), dan dana bagi hasil (DBH) dari penerimaan pajak dan sumber daya alam, yang dikelompokkan sebagai pendapatan transfer dalam Anggaran Pendapatan dan Belanja Daerah, dan yang merupakan sumber pendanaan bagi daerah dalam pelaksanaan desentralisasi yang alokasinya tidak dapat dipisahkan satu dengan yang lain mengingat tujuan masing-masing jenis penerimaan tersebut saling mengisi dan melengkapi. Dana Perimbangan bertujuan untuk menciptakan keseimbangan keuangan antara pemerintah pusat dan pemerintah daerah serta antar-pemerintah daerah.

\section{Belanja Modal}

Dewi (2006) dan Syaiful (2008) mengutarakan bahwa belanja modal adalah pengeluaran yang dilakukan dalam rangka pembentukan modal yang sifatnya menambah aset tetap/inventaris yang memberikan manfaat lebih dari satu periode akuntansi, termasuk di dalamnya adalah pengeluaran untuk belanja pemeliharaan yang sifatnya mempertahankan atau menambah masa manfaat, meningkatkan kapasitas dan kualitas aset.

Untuk menambah aset tetap, pemerintah daerah mengalokasikan dana dalam bentuk anggaran belanja modal dalam APBD. Alokasi belanja modal ini didasarkan pada kebutuhan daerah akan sarana dan prasarana, baik untuk kelancaran pelaksanaan tugas pemerintahan maupun untuk fasilitas publik.

\section{Belanja Pemeliharaan}

Belanja pemeliharaan adalah kewajiban yang timbul akibat hak atas pengeluaran anggaran yang dilakukan oleh pemerintah dengan tujuan untuk mempertahankan aset tetap atau aset lainnya yang sudah ada ke dalam kondisi yang normal tanpa memperhatikan besar atau kecil.

Belanja pemeliharaan terjadi pada semua satuan kerja atau unit organisasi pemerintah daerah karena semua memiliki aset tetap. Karena sifatnya yang rutin, belanja pemeliharaan tidak tergantung pada Tupoksi satuan kerja, tetapi tergantung pada 
jumlah aset yang dimiliki. Dengan demikian, belanja pemeliharaan bukan merupakan biaya aktivitas yang bersifat variabel.

\section{Pengaruh Sumber Pendapatan Daerah Terhadap Belanja Modal Pengaruh Pendapatan Asli Daerah Terhadap Belanja Modal}

Infrastruktur dan sarana prasarana yang ada di daerah akan berdampak pada pertumbuhan ekonomi. Jika sarana dan prasarana memadai, maka masyarakat dapat melakukan aktivitas sehari-harinya secara aman dan nyaman yang akan berpengaruh pada tingkat produktivitasnya yang semakin meningkat, dan dengan adanya infrastruktur yang memadai akan menarik investor untuk membuka usaha di daerah tersebut. Dengan bertambahnya investor akan meningkatkan pendapatan asli daerah, maka akan berdampak pada bertambahnya belanja modal.

\section{Pengaruh Dana Perimbangan Terhadap Belanja Modal}

Sejak diterapkannya desentralisasi fiskal, pemerintah pusat mengharapkan daerah dapat mengelola sumber daya yang dimiliki sehingga tidak hanya mengandalkan dana perimbangan. Apabila ketergantungan pemerintah daerah terhadap transfer pemerintah pusat (dana perimbangan) semakin tinggi, akan memberikan adanya indikasi kuat bahwa perilaku belanja daerah, khususnya belanja modal akan sangat dipengaruhi sumber pendapatan ini. Di beberapa daerah peran dana perimbangan sangat signifikan karena kebijakan belanja modal lebih didominasi oleh jumlah dana perimbangan daripada pendapatan asli daerah.

\section{Pengaruh Belanja Modal Terhadap Belanja Pemeliharaan}

Belanja modal memiliki konsekuensi diperolehnya aset tetap (fixed asset) pada saat belanja tersebut direalisasi sepenuhnya atau outputnya sudah diperoleh. Hal ini bermakna adanya penambahan aset tetap yang dimiliki oleh pemerintah daerah. Dalam perspektif manajemen keuangan dan akuntansi, selain diperhitungkan cost untuk penggunaan aset tersebut dalam operasional organisasi dalam bentuk depresiasi, juga harus diperhitungkan cost untuk pemeliharaan aset tersebut sehingga dapat dimanfaatkan secara efektif sesuai dengan kegunaannya. Belanja pemeliharaan dikeluarkan secara rutin atau terjadi berulang-ulang setiap tahun (recurrent) atas aset tetap yang dimiliki oleh pemerintah daerah.

\section{KERANGKA PEMIKIRAN}

Untuk melihat kerangka penelitian yang akan dilakukan oleh penulis tentang pengaruh sumber pendapatan daerah terhadap belanja modal dan pengaruh belanja modal terhadap belanja pemeliharaan, dapat dilihat dalam gambar berikut ini: 


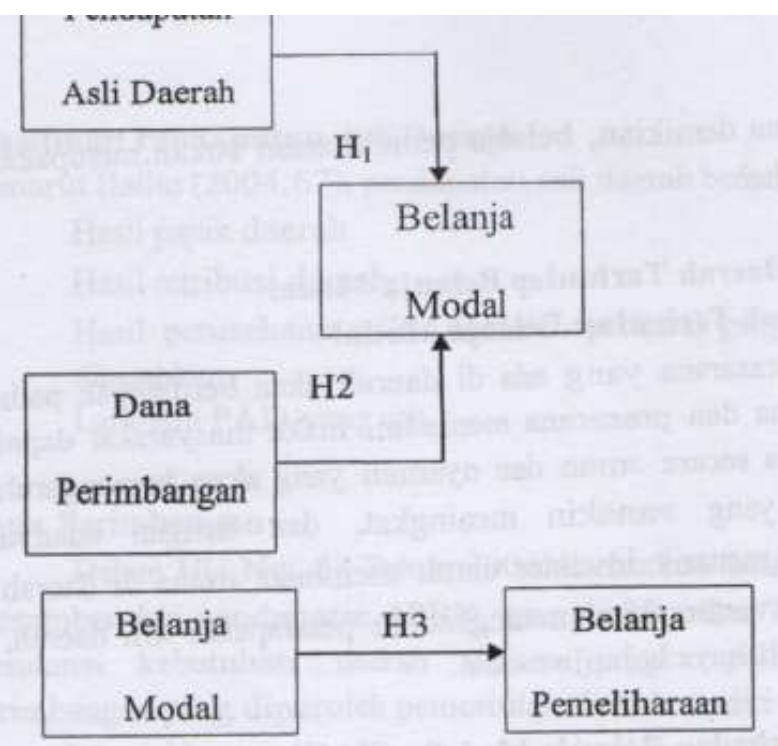

\section{PENGEMBANGAN HIPOTESIS}

Hipotesis adalah dugaan atau jawaban sementara terhadap objek penelitian yang disusun oleh peneliti yang kemudian akan diuji kebenarannya melalui analisis data yang relevan dan kebenarannya akan diketahui setelah dilakukan penelitian (Mudrajad, 2003:48). Berdasarkan latar belakang masalah, rumusan masalah, tinjauan teoritis, dan kerangka penelitian, hipotesis yang akan diuji dalam penelitian ini sebagai berikut:

\section{Pengaruh Sumber Pendapatan Daerah Terhadap Belanja Modal}

Secara konseptual perubahan pendapatan akan berpengaruh terhadap belanja atau pengeluaran, namun tidak selalu seluruh tambahan pendapatan tersebut akan dialokasikan dalam belanja.

Abdullah \& Halim (2006) menemukan bahwa sumber pendapatan daerah berupa pendapatan asli daerah dan dana perimbangan berpengaruh terhadap belanja modal. Meskipun proporsi pendapatan asli daerah maksimal hanya sebesar $10 \%$ dari total pendapatan daerah, kontribusinya terhadap pengalokasian anggaran cukup besar, terutama bila dikaitkan dengan kepentingan politis. Sementara dana perimbangan merupakan sumber pendapatan utama pemerintah daerah (sekitar 90-95\%), namun bersifat contingent karena ditentukan oleh pemerintah pusat.

Berdasarkan temuan dan analisis di atas, hipotesis yang disusun untuk melihat pengaruh sumber pendapatan daerah (berupa pendapatan asli daerah dan dana perimbangan) terhadap belanja modal adalah:

$H_{l}$ : Pendapatan asli daerah berpengaruh terhadap belanja modal pada pemerintah kabupaten/kota di Provinsi Jawa Tengah dan Provinsi Daerah Istimewa Yogyakarta tahun 2006-2010 
$\mathrm{H}_{2}$ : Dana perimbangan berpengaruh terhadap belanja modal pada pemerintah kabupaten/kota di Provinsi Jawa Tengah dan Provinsi Daerah Istimewa Yogyakarta tahun 2006-2010.

\section{Pengaruh Belanja Modal Terhadap Belanja Pemeliharaan}

Penelitian Bland \& Nunn (1992) memberikan bukti empiris yang cukup lengkap tentang pengaruh antara belanja modal dan belanja pemeliharaan. Meskipun para manajer di sektor publik, termasuk pemerintah, menyadari bahwa realisasi belanja modal memiliki konsekuensi akan adanya belanja pemeliharaan, namun dalam pembuatan keputusan pengalokasian dan belanja modal merupakan hal yang terpisah. Hal ini menunjukkan seolah-olah tidak ada pengaruh antara belanja modal dan belanja pemeliharaan.

Berdasarkan temuan Bland \& Nunn (1992), prediksi atas pengaruh antara belanja modal dan belanja pemeliharaan tergantung pada beberapa faktor, seperti sifat dari belanja modal (sebagai pengganti aset tetap yang telah ada atau sebagai peningkatan kapasitas). Mereka berpandangan bahwa belanja modal akan berpengaruh terhadap belanja pemeliharaan setahun ke depan dan mungkin saja hal ini bermakna adanya upaya pemerintah daerah untuk meningkatkan kapasitas pelayanan kepada publik. Artinya, konsekuensi fiskal belanja modal adalah signifikan dan dampaknya terhadap belanja pemeliharaan dapat terasa selama beberapa tahun ke depan. Sementara Kamensky (1984) berargumen perlunya menghubungkan keputusan belanja modal dengan keputusan belanja pemeliharaan. Karo-Karo (2006) justru menemukan bahwa di Indonesia tidak ada pengaruh belanja modal terhadap belanja pemeliharaan.

Pendapat-pendapat di atas memerlukan pembuktian empiris lebih jauh tentang pengaruh belanja modal terhadap belanja pemeliharaan untuk konteks pemerintah daerah di Indonesia. Oleh karena itu, hipotesis yang akan diuji dapat dinyatakan sebagai berikut:

$H_{3}$ : Belanja modal berpengaruh terhadap belanja pemeliharaan pada pemerintah kabupaten/kota Provinsi Jawa Tengah dan Provinsi Daerah Istimewa Yogyakarta tahun 2006-2010

\section{METODA PENELITIAN}

\section{Populasi, Sampel, dan Teknik Pengambilan Sampel}

Menurut Sekaran (2006:121), "populasi (population) adalah keseluruhan kelompok orang, kejadian, atau hal minat yang ingin peneliti investigasi". Yang menjadi populasi dalam penelitian ini adalah seluruh pemerintah kabupaten dan kota yang ada di Provinsi Jawa Tengah dan Provinsi Daerah Istimewa Yogyakarta tahun 2006-2010, yaitu sebanyak 40 kabupaten/kota, terdiri dari 33 kabupaten dan 7 kota.

Sampel adalah sekelompok atau beberapa bagian dari suatu populasi (Indriantoro \& Supomo, 1999). Penelitian ini menggunakan teknik pengambilan sampel 
bertujuan (purposive sampling), yaitu teknik pengambilan sampel dari populasi berdasarkan suatu kriteria tertentu (Jogiyanto, 2003). Beberapa kriteria yang ditentukan oleh peneliti dalam pengambilan sampel adalah sebagai berikut:

a. Daerah yang diikutkan sebagai sampel adalah daerah yang sudah melaporkan Laporan Realisasi APBD dengan lengkap dalam kurun waktu penelitian selama periode 2006-2010 pada Badan Pusat Statistik (BPS).

b. Laporan realisasi APBD pemerintah kabupaten dan kota yang memakai format berdasarkan pengklasifikasian rekening menurut Permendagri No. 13 Tahun 2006, yang terdiri atas pendapatan, belanja, dan pembiayaan.

\section{Jenis dan Sumber Data}

Jenis data yang digunakan dalam penelitian ini adalah data sekunder yang bersifat data kuantitatif. Data yang dikumpulkan bersumber dari dokumen Laporan Perhitungan APBD atau Laporan Realisasi APBD Pemerintah Kabupaten dan Kota di Provinsi Jawa Tengah dan Provinsi Daerah Istimewa yang diperoleh dari situs resmi Direktorat Jenderal Perimbangan Keuangan Pusat dan Daerah (http://www.djpkpd.go.id) secara online (download), Badan Pusat Statistik Provinsi Daerah Istimewa Yogyakarta, dan Bappeda Provinsi Jawa Tengah dan Provinsi Daerah Istimewa Yogyakarta. Data yang dikumpulkan mengenai jumlah realisasi anggaran pendapatan daerah dan belanja daerah. Data pendapatan daerah berupa Pendapatan Asli Daerah dan Dana Perimbangan. Sedangkan data belanja daerah berupa Belanja Pemeliharaan dan Belanja Modal. Data tersebut terdiri dari 5 tahun untuk setiap pemerintah kabupaten dan kota, yakni tahun 2006, 2007, 2008, 2009, dan 2010.

\section{Teknik Pengumpulan Data}

Untuk mencapai tujuan dan pembuktian hipotesis, teknik pengumpulan data yang digunakan dalam penelitian ini adalah:

1) Studi dokumentasi, yakni peneliti melakukan pengumpulan data sekunder yang diperoleh dari Badan Pusat Statistik Provinsi Daerah Istimewa Yogyakarta, situs resmi Direktorat Jenderal Perimbangan Keuangan Pusat dan Daerah (http://www.djpkpd.or.id) secara online (download), dan Bappeda Provinsi Jawa Tengah dan Provinsi Daerah Istimewa Yogyakarta.

2) Studi kepustakaan, yakni teknik pengumpulan data yang digunakan sebagai pembanding dengan mencari teori yang relevan dan menunjang melalui bahan kepustakaan berupa buku, jurnal, artikel, peraturan perundang-undangan yang berlaku, atau literatur lainnya yang berkaitan dengan permasalahan yang diteliti. 


\section{Definisi Operasional dan Pengukuran Variabel}

Variabel yang digunakan dalam penelitian ini, antara lain:

a) Variabel Independen (Independent Variable)

Dalam penelitian ini yang menjadi variabel independen untuk hipotesa 1 dan 2 adalah Pendapatan Asli Daerah dan Dana Perimbangan, sedangkan untuk hipotesa 3
adalah Belanja Modal.

1) Pendapatan Asli Daerah

Pendapatan Asli Daerah dalam penelitian ini diartikan sebagai total realisasi pendapatan yang diperoleh daerah yang bersumber dari hasil pajak daerah, hasil retribusi daerah, hasil perusahaan milik daerah serta hasil pengelolaan kekayaan daerah yang dipisahkan, dan lain-lain Pendapatan Asli Daerah yang sah (Mardiasmo, 2002). Variabel ini diukur dari jumlah realisasi anggaran Pendapatan Asli Daerah tahun 2006-

2) Dana Perimbangan

Dana Perimbangan selain dimaksudkan untuk membantu daerah dalam mendanai kewenangannya juga bertujuan untuk mengurangi ketimpangan sumber pendapatan pemerintah antara pemerintah pusat dan pemerintah daerah serta untuk mengurangi kesenjangan pendapatan pemerintah antar-daerah. Variabel ini diukur dari jumlah realisasi anggaran Dana Perimbangan tahun 2006-2010.

3) Belanja Modal

Belanja Modal dalam penelitian ini diartikan sebagai pengeluaran pemerintah daerah yang memberikan manfaat melebihi satu tahun anggaran atau periode akuntansi yang dilakukan dalam rangka menambah aset tetap atau kekayaan daerah kabupaten dan kota. Variabel ini diukur dari jumlah realisasi anggaran Belanja Modal tahun 2006-

\section{b. Variabel Dependen (Dependent Variable)}

Dalam penelitian ini yang menjadi variabel dependen untuk hipotesa 1 dan 2 adalah Belanja Modal, sedangkan untuk hipotesa 3 adalah Belanja Pemeliharaan.

Belanja Pemeliharaan dalam penelitian ini diartikan sebagai pengeluaran daerah kabupaten dan kota yang digunakan untuk menjaga agar aset daerah senantiasa dalam kondisi siap digunakan. Variabel ini diukur dari jumlah realisasi anggaran Belanja
Pemeliharaan tahun 2006-2010.

\section{TEKNIK ANALISIS DATA}

Data diolah dengan menggunakan Software Eviews versi 4.1

\section{Analisis Deskriptif}

Analisis deskriptif adalah analisis yang menjelaskan tentang gambaran/deskripsi data-data variabel yang digunakan yang dilihat dari nilai minimum, nilai maksimum, 
nilai rata-rata (mean), standar deviasi, variance, kurtosis, kemencengan distribusi (skewnes). Analisis ini digunakan untuk memberikan gambaran awal tentang kondisi Pendapatan Asli Daerah, Dana Perimbangan, Belanja Modal, dan Belanja Pemeliharaan.

\section{Analisis Model Regresi Data Panel}

Data dalam penelitian ini merupakan kombinasi dari data silang tempat (cross section), yaitu data yang dikumpulkan pada suatu titik waktu, dan data runtut waktu (time series), yaitu data yang secara kronologis disusun menurut waktu pada suatu variabel tertentu, yang disebut dengan data panel (pooled data) (Mudrajad, 2003). Penelitian ini menggunakan data yang diambil dari 40 daerah kabupaten/kota (cross section) selama periode waktu 5 tahun (time series), yaitu tahun 2006 sampai dengan tahun 2010.

Untuk mendukung pengujian hipotesis yang menggunakan analisis regresi data panel, maka sebelumnya dilakukan pengujian untuk menentukan model yang tepat.

Ada tiga model alternatif dalam regresi data panel, yaitu:
a. Common Effect
b. Fixed Effect
c. Random Effect

Penentuan model dalam regresi data panel dapat dilakukan melalui pengujian berikut:

1) Uji Chow (Common vs Fixed)

Pengujian ini dilakukan untuk menentukan model antara common effect atau fixed effect yang akan digunakan dalam regresi data panel. Uji Chow dilakukan dengan hipotesis sebagai berikut: $\mathrm{H}_{0}$ : model common effect dan $\mathrm{H}_{1}$ : model fixed effect. Rumus uji Chow:

$$
\text { CHOW }=\frac{(\text { RRSS }- \text { URSS }) / \mathrm{N}-1}{(1-R R S S) / N \cdot T-N-K}
$$

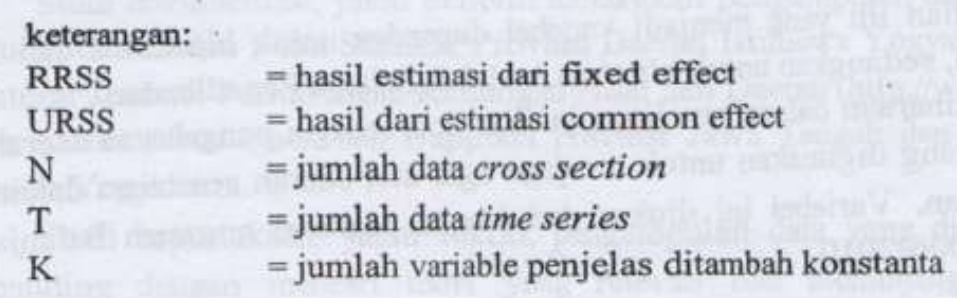

Apabila hasil dari penghitungan tersebut diketahui bahwa nilai F-statistik lebih kecil dari nilai F-tabel dengan tingkat signifikansi $\alpha=5 \%$, maka Ho diterima. Dalam hal ini, model yang akan digunakan dalam regresi data panel adalah common effect. Sebaliknya apabila nilai F-statistik lebih besar dari nilai F-tabel dengan tingkat pengujian $\alpha=5 \%$, maka Ho ditolak. Dalam hal ini, model pendekatan yang akan digunakan dalam regresi data panel adalah fixed effect (Modul Pelatihan Ekonometrika Dasar dan Lanjutan Sesi X 2006: 10).

Jurnal Reksa Vol.I No.1 Februari 2012 


\section{2) Uji Hausman (Fixed vs Random)}

Penulis tidak melanjutkan dengan uji Hausman (berakhir dengan uji Chow) dengan alasan bila $\mathrm{N}$ besar dan $\mathrm{T}$ kecil, maka hasil estimasi kedua model dapat berbeda secara signifikan. Apabila kita meyakini bahwa unit cross section yang kita pilih dalam penelitian diambil secara acak (random), maka model random effect harus digunakan. Sebaliknya, apabila kita meyakini bahwa unit cross section yang kita pilih dalam penelitian tidak diambil secara acak (random), maka kita harus menggunakan model fixed effect (Modul Pelatihan Ekonometrika Dasar \& Lanjutan Sesi X 2006:11).

\section{Uji Asumsi Klasik}

Teknik-teknik estimasi yang menggunakan data panel mengakomodir masalah heteroskedastisitas karena berhubungan dengan variabel-variabel spesifik perusahaan (data cross section), masalah autokorelasi (data time series), dan memungkinkan mempelajari lebih kompleks mengenai perilaku yang ada dalam model sehingga pengujian data panel tidak memerlukan uji asumsi klasik (Gujarati, 2003).

\section{Uji Hipotesis}

Dalam melakukan pengujian hipotesis, peneliti melakukan dua uji regresi, yaitu regresi berganda (multiple regression) dan regresi sederhana (simple regression).

\section{Regresi berganda}

Analisis regresi berganda dilakukan untuk menguji hipotesa $1\left(\mathrm{H}_{1}\right)$, yakni untuk melihat pengaruh Pendapatan Dsli daerah terhadap Belanja Modal dan hipotesa $2\left(\mathrm{H}_{2}\right)$, yakni untuk melihat pengaruh Dana Perimbangan terhadap Belanja Modal. Untuk menguji hipotesis tersebut, persamaan regresinya sebagai berikut:

$$
\mathbf{Y}=\mathbf{a}+\mathbf{b}_{1} \mathbf{x}_{1}+\mathbf{b}_{2} \mathbf{x}_{2}+\mathbf{e}
$$

keterangan:

$\mathrm{Y}=$ Belanja Modal sebagai variabel dependen

$\mathrm{a}=$ konstanta

$b_{1}=$ koefisien regresi Pendapatan Asli Daerah

$\mathrm{x}_{1}=$ Pendapatan Asli Daerah sebagai variabel independen

$\mathrm{b}_{2}=$ koefisien regresi Dana Perimbangan

$\mathrm{x}_{2}=$ Dana Perimbangan sebagai variabel independen

e $=$ error/kesalahan estimasi

\section{Kriteria Pengujian Hipotesis}

a) Koefisien determinasi

Pengujian koefisien determinasi digunakan untuk mengukur proporsi atau persentase pengaruh variabel independen yang diteliti terhadap variasi naik turunnya 
variabel dependen. Besarnya koefisien determinasi berkisar antara nol sampai satu $(0 \leq$ $\mathrm{R}^{2} \leq 1$ ). Hal ini berarti bila $\mathrm{R}^{2}=0$, menunjukkan tidak adanya pengaruh variabel independen terhadap variabel dependen. Bila $R^{2}$ semakin besar mendekati satu, menunjukkan semakin kuatnya pengaruh variabel independen terhadap variabel dependen (semakin besar kemampuan model yang dihasilkan dalam menjelaskan perubahan nilai variabel dependen). Sebaliknya bila $R^{2}$ semakin kecil mendekati nol, menunjukkan semakin kecilnya pengaruh variabel independen terhadap variabel dependen (semakin kecil kemampuan model yang dihasilkan dalam menjelaskan perubahan nilai variabel dependen).

b) Uji t-Statistik

Pengujian ini bertujuan untuk mengetahui pengaruh masing-masing variabel independen terhadap variabel dependen dengan tingkat signifikansi $\alpha=5 \%$.

Bentuk pengujian:

$\mathrm{H}_{0}: \mathrm{b} 1=\mathrm{b} 2=0$, artinya Pendapatan Asli Daerah dan Dana Perimbangan secara parsial tidak berpengaruh terhadap pengalokasian anggaran Belanja Modal

$\mathrm{H}_{\mathrm{a}}: \mathrm{b} 1 \neq \mathrm{b} 2 \neq 0$, artinya Pendapatan Asli Daerah dan Dana Perimbangan secara parsial berpengaruh terhadap pengalokasian anggaran Belanja Modal. Dasar pengambilan keputusan:

a. Jika probabilitas t-statistik $>0,05$, maka $\mathrm{H}_{0}$ diterima.

b. Jika probabilitas t-statistik $<0,05$, maka $\mathrm{H}_{0}$ ditolak.

c) Uji F-Statistik

Pengujian ini bertujuan untuk mengetahui pengaruh semua variabel independen terhadap variabel dependen dengan tingkat signifikansi $\alpha=5 \%$.

Bentuk pengujiannya:

$\mathrm{H}_{0}$ : $\quad$ b1 $=\mathrm{b}_{2}=0$, artinya Pendapatan Asli Daerah dan Dana Perimbangan secara simultan tidak berpengaruh terhadap pengalokasian anggaran Belanja Modal

$\mathrm{H}_{\mathrm{a}}$ : $\quad \mathrm{b} 1 \neq \mathrm{b} 2 \neq 0$, artinya Pendapatan Asli Daerah dan Dana Perimbangan secara simultan berpengaruh terhadap pengalokasian anggaran Belanja Modal

Dasar pengambilan keputusan:

a. Jika probabilitas F-statistik $>0,05$, maka $\mathrm{H}_{0}$ diterima.

b. Jika probabilitas F-statistik $<0,05$, maka $\mathrm{H}_{0}$ ditolak.

\section{Regresi Sederhana}

Analisis regresi sederhana dilakukan untuk menguji hipotesis $3\left(\mathrm{H}_{3}\right)$, yakni untuk melihat pengaruh Belanja Modal terhadap Belanja Pemeliharaan. Untuk menguji hipotesis tersebut, persamaan regresinya sebagai berikut:

$$
\mathbf{Y}=\mathbf{a}+\mathbf{b} \mathbf{x}+\mathbf{e}
$$

keterangan:

$Y=$ Belanja Pemeliharaan sebagai variabel dependen

$a=$ konstanta yang menunjukkan besar nilai $\mathrm{y}$ bila nilai $\mathrm{x}=0$

Jurnal Reksa Vol.I No.1 Februari 2012 
$b=$ koefisien regresi yang menunjukkan besar nilai $\mathrm{x}$ dalam menentukan besar $\mathrm{y}$

$x=$ Belanja Modal sebagai variabel independen

$e=$ error $/$ kesalahan estimasi

\section{PEMBAHASAN}

Berdasarkan hasil penghitungan uji Chow, maka model yang akan digunakan dalam regresi data panel adalah model Fixed Effect. Pengujian hipotesis bisa dilihat di table 1

Table 1

Hasil regresi

\begin{tabular}{|c|c|c|c|c|}
\hline Variable & Coefficient & Std. Error & t-Statistic & Prob. \\
\hline PAD? & -0.550242 & 0.105942 & -5.193822 & 0.0000 \\
\hline DAPER? & -0.005007 & 0.034057 & -0.147005 & 0.8833 \\
\hline BM? & -0.043651 & 0.011508 & -3.793114 & 0.0002 \\
\hline
\end{tabular}

Sumber: hasil pengolahan data sekunder

\section{Pengujian Hipotesa 1}

Berdasarkan tabel ringkasan hasil estimasi model fixed effect, variabel Pendapatan Asli Daerah menunjukkan nilai probabilitas sebesar 0,0000 yang nilainya lebih kecil dari tingkat signifikansi yang ditolerir yaitu 0,05 , maka $\mathrm{H}_{0}$ ditolak dan menerima $\mathrm{H}_{\mathrm{a}}$ atau dengan kata lain Pendapatan Asli Daerah berpengaruh terhadap Belanja Modal. Dengan demikian hipotesa 1 yang menyatakan bahwa Pendapatan Asli Daerah berpengaruh terhadap Belanja Modal dapat didukung.

\section{Pengujian Hipotesa 2}

Berdasarkan tabel ringkasan hasil estimasi model fixed effect, variabel Dana Perimbangan menunjukkan nilai probabilitas sebesar 0,8833 yang nilainya lebih besar dari tingkat signifikansi yang ditolerir yaitu 0,05 , maka $\mathrm{H}_{0}$ diterima dan menolak $\mathrm{H}_{\mathrm{a}}$ atau dengan kata lain Dana Perimbangan tidak berpengaruh terhadap Belanja Modal. Dengan demikian hipotesa 2 yang menyatakan bahwa Dana Perimbangan berpengaruh terhadap Belanja Modal tidak dapat didukung.

\section{Pengujian Hipotesa 3}

Berdasarkan tabel ringkasan hasil estimasi model fixed effect, variabel Belanja Modal menunjukkan nilai probabilitas sebesar 0,0002 yang nilainya lebih kecil dari tingkat signifikansi yang ditolerir yaitu 0,05 , maka $\mathrm{H}_{0}$ ditolak dan menerima $\mathrm{H}_{\mathrm{a}}$ atau dengan kata lain Belanja Modal berpengaruh terhadap Belanja Pemeliharaan. Dengan demikian hipotesa 3 yang menyatakan bahwa Belanja Modal berpengaruh terhadap Belanja Pemeliharaan dapat didukung. 


\section{KESIMPULAN}

1. Sumber pendapatan daerah berupa Pendapatan Asli Daerah berpengaruh terhadap Belanja Modal pada pemerintah kabupaten/kota di Provinsi Jawa Tengah dan Provinsi Daerah Istimewa Yogyakarta tahun 2006-2010.

2. Sumber pendapatan daerah berupa Dana Perimbangan tidak berpengaruh terhadap Belanja Modal pada pemerintah kabupaten/kota di Provinsi Jawa Tengah dan Provinsi Daerah Istimewa Yogyakarta tahun 2006-2010.

3. Belanja Modal berpengaruh terhadap Belanja Pemeliharaan pada pemerintah kabupaten/kota di Provinsi Jawa Tengah dan Provinsi Daerah Istimewa Yogyakarta tahun 2006-2010.

4. Sampel dalam penelitian ini dibatasi pada kabupaten/kota di provinsi tertentu, yaitu kabupaten/kota di Provinsi Jawa Tengah dan Provinsi Daerah Istimewa Yogyakarta.

5. Penelitian ini hanya memasukkan 2 variabel independen yang diduga dapat mempengaruhi Belanja Modal, yaitu Pendapatan Asli Daerah dan Dana Perimbangan. Penelitian ini juga hanya memasukkan 1 variabel independen yang diduga dapat mempengaruhi Belanja Pemeliharaan, yaitu Belanja Modal.

6. Periode pengamatan dibatasi dari tahun 2006 sampai dengan tahun 2010.

7. Penelitian ini tidak membahas kebijakan pemerintah daerah dalam penyusunan anggaran Pendapatan Asli Daerah, Dana Perimbangan, Belanja Modal, dan Belanja Pemeliharaan.

8. Terjadinya perubahan peraturan dalam pembuatan anggaran khususnya Belanja Pemeliharaan yang sejak tahun 2007 sudah langsung dimasukkan ke dalam anggaran masing-masing satuan/unit kerja sesuai dengan Permendagri No. 13 Tahun 2006 sehingga timbul sedikit kendala dalam pengumpulan data khususnya untuk data Belanja Pemeliharaan tahun 2007-2010. Akhirnya diambil data Belanja Pemeliharaan dari Bappeda Provinsi Jawa Tengah dan Provinsi Daerah Istimewa Yogyakarta. Data yang masuk ke Bappeda Provinsi Jawa Tengah dan Provinsi Daerah Istimewa Yogyakarta adalah Belanja Pemeliharaan yang nilai nominalnya cukup besar karena untuk nilai nominal Belanja Pemeliharaan yang kecil biasanya diberdayakan sendiri oleh masingmasing satuan/unit kerja yang ada di kabupaten/kota Provinsi Jawa Tengah dan Provinsi Daerah Istimewa Yogyakarta.

9. Bagi peneliti berikutnya di masa mendatang disarankan agar dapat memperluas kabupaten/kota yang akan diteliti, seperti kabupaten/kota di luar Provinsi Jawa Tengah dan Provinsi Daerah Istimewa Yogyakarta atau seluruh kabupaten/kota yang ada di Indonesia.

10. Bagi peneliti berikutnya di masa mendatang disarankan agar dapat menambah variabel keuangan lainnya, seperti belanja rutin, DAU, DAK, DBH, maupun variabel non-keuangan, seperti kebijakan pemerintah daerah, atau variabel lainnya yang ikut mempengaruhi Belanja Modal ataupun Belanja Pemeliharaan yang diharapkan penambahan variabel-variabel tersebut dapat melengkapi penelitian-penelitian berikutnya di masa mendatang agar menjadi lebih baik.

Jurnal Reksa Vol.I No.1 Februari 2012

Page 60 
11. Bagi peneliti berikutnya di masa mendatang disarankan agar dapat menggunakan data yang mempunyai rentang waktu yang lebih dari lima tahun untuk diteliti sehingga lebih mampu untuk dapat dilakukan generalisasi atas hasil penelitian tersebut.

12. Bagi peneliti berikutnya di masa mendatang disarankan agar lebih hati-hati dalam mengikuti perubahan peraturan perundang-undangan yang berlaku sehingga tidak terjadi kendala dalam pengumpulan data.

13. Perlu dikaji lebih jauh bagaimana proses pengalokasian Belanja Modal dalam anggaran pemerintah daerah. Hal ini untuk memberikan bukti apakah Belanja Modal merupakan manifestasi dari kebijakan untuk menambah kapasitas aset, meningkatkan efisiensi, mengganti aset yang telah dan tidak ekonomis, atau pelaksanaan kebijakan padat karya atau padat modal.

14. Aspek politik berperan besar dalam pengalokasian anggaran Belanja Modal. Untuk itu, perlu penelitian lebih mendalam bagaimana faktor politik berperan dalam penentuan besaran Belanja Modal sehingga dapat dipahami lebih jauh faktor-faktor lain yang mempengaruhi Belanja Modal dan Belanja Pemeliharaan.

\section{DAFTAR PUSTAKA}

Abdullah, Syukriy, dan Abdul Halim. 2006. "Studi Atas Belanja Modal Pada Anggaran Pemerintah Daerah Dalam Hubungannya Dengan Belanja Pemeliharaan dan Sumber Pendapatan" Jurnal Akuntansi Pemerintah (November), Vol. 2, No 2,
hal. 17-35.

Azwar, Saifudin. 2001. Metode Penelitian. Yogyakarta: Pustaka Pelajar Offset. Badan Pusat Statistik. 2006-2010. Statistik Keuangan Pemerintah Daerah Provinsi.
Jakarta.

Bland, Robert, dan Samuel Nunn. 1992. "The impact of capital spending on municipal operating budgets" Public Budgeting \& Finance (Summer): 32-47.

Christy, Fhino Andrea, dan Adi Priyo Hari. 2009. Hubungan antara Dana Alokasi Umum, Belanja modal, dan Kualitas Pembangunan Manusia. Artikel pada The 3rd National Conference UKWMS Surabaya.

Darwanto dan Yulia Yustika Sari. 2007. "Pengaruh Pertumbuhan Ekonomi, Pendapatan Asli Daerah, Dana Alokasi Umum Terhadap Pengalokasian Belanja Modal" Simposium Nasional Akuntansi X Makasar (Juli).

Dewi, Adha. 2006. Kajian Penerapan Akuntansi Biaya pada Anggaran Belanja Daerah Kota Singkawang. Yogyakarta: Universitas Islam Indonesia.

Gujarati, Damodar. 2003. Ekonometrika Dasar: Edisi Keenam. Jakarta: Erlangga. 
Halim, Abdul. 2002. Analisis Varian Pendapatan Asli Daerah dalam Laporan Perhitungan Anggaran Pendapatan dan Belanja Daerah Kabupaten/Kota di Indonesia. Disertasi. Yogyakarta: Universitas Gadjah Mada.

\section{Akuntansi Sektor Publik. Jakarta: Salemba Empat.}

Indriantoro, Nur, dan Bambang Supomo. 1999. Metodologi Penelitian Bisnis untuk Akuntasi dan Manajemen. Yogyakarta: BPFE.

Jogiyanto, H.M. 2003. Teori Portofolio dan Analisis Investasi. Edisi 1. Yogyakarta: BPFE.

Kamensky, John M. 1984. "Budgeting for state and local infrastructure: Developing a strategy" Public Budgeting and Finance (Autumn): 3-17.

Karo-Karo, Syukur Selamat. 2006. Hubungan Belanja Modal dengan Belanja Operasional dan Pemeliharaan pada Pemerintah Kabupaten/Kota di Pulau Jawa. Tesis. Yogyakarta: Universitas Gadjah Mada.

Kuncoro, Mudrajad. 2003. Metode Riset Untuk Bisnis dan Ekonomi. Jakarta: Erlangga. KSAP. 2005. Standar Akuntansi Pemerintahan. Bandung: Fokusmedia.

Lembaran Negara RI. 1999. Undang-undang Republik Indonesia No. 22 Tahun 1999 tentang Pemerintah Daerah.

1999. Undang-undang Republik Indonesia No. 25 Tahun 1999 tentang Perimbangan Keuangan antara Pemerintah Pusat dan Daerah.

2000. Peraturan Pemerintah Republik Indonesia No. 105 Tahun 2000 tentang Pengelolaan dan Pertanggungjawaban Keuangan Daerah.

2002. Keputusan Menteri Dalam Negeri No. 29 Tahun 2002 tentang Pedoman Pengurusan, Pertanggungjawaban dan Pengawasan Keuangan Daerah, serta Tata Cara Penyusunan APBD, Pelaksanaan Tata Usaha Keuangan Daerah dan Penyusunan Perhitungan APBD.

2004. Undang-Undang Republik Indonesia No. 1 Tahun 2004 tentang Perbendaharaan Negara.

2004. Undang-Undang Republik Indonesia No. 32 Tahun 2004 tentang Pemerintah Daerah.

2004. Undang-Undang Republik Indonesia No. 33 Tahun 2005 tentang Perimbangan Keuangan Antara Pemerintah Pusat dan Daerah.

2005. Peraturan Pemerintah Republik Indonesia No. 58 Tahun 2000 tentang Pengelolaan Keuangan Daerah. 
tentang Dana Perimbangan.
2005erintah Republik Indonesia No. 55 Tahun 2005

2006. Peraturan Menteri Dalam Negeri No. 13 Tahun 2006 tentang Pedoman Pengelolaan Keuangan Daerah.

2007. Peraturan Pemerintah Republik Indonesia No. 38 Tahun 2007 tentang Pembagian Urusan Pemerintahan Antara Pemerintah, Pemerintah Daerah Provinsi, dan Pemerintah Daerah Kabupaten/ Kota.

Mardiasmo. 2002. Akuntansi Sektor Publik. Yogyakarta: Andi Yogyakarta.

Moisio, Antti. 2002. Essays on Finish Municipal Finance and Intergovernmental Grants. Helsinki: Government Institute for Economic Research.

Nachrowi, D Nachrowi dan Hardius Usman. 2006. Ekonometrika untuk Analisis Ekonomi
dan Keuangan Pagano, Michael. 1984. "Notes on capital budgeting" Public Budgeting \& Finance
(Autumn): $31-40$.

Pelatihan Ekonometrika Dasar dan Lanjutan. Dosen PTS Ekonomi Se-Jawa dan
Sumatera. 2006. Bogor.

Saragih, Juli Panglima. 2003. Desentralisasi Fiskal dan Keuangan Daerah dalam Otonomi. Jakarta: Ghalia Indonesia.

Sari, Noni Puspita, dan Yahya Idhar. 2009. "Pengaruh Dana Alokasi Umum (DAU) dan Pendapatan Asli Daerah (PAD) Terhadap Belanja Langsung pada Pemerintah Kabupaten/Kota di Provinsi Riau" Jurnal Akuntansi (Agustus), Vol. 42.

Sembiring, Sri Hayati. 2009. Analisis Pengaruh Belanja Modal dan Pendapatan Asli Daerah Terhadap Belanja Pemeliharaan Dalam Realisasi Anggaran Universitas Sumatera Utara

Sidik, Machfud, B. Raksasa Mahi, Robert Simanjuntak, dan Bambang Brodjonegoro. 2002. Dana Alokasi Umum-Konsep, Hambatan, dan Prospek di Era Otonomi Daerah. Jakarta: Buku Kompas.

Soekarwo. 2003. Berbagai Permasalahan Keuangan Daerah. Jakarta: Grafindo. Sugiarto. 2006. Metode Statistika Untuk Bisnis dan Ekonomi. Jakarta: Gramedia
Pustaka Utama.

Syaiful. 2008. Pengertian dan Perlakuan Akuntansi Belanja Barang dan Belanja Modal dalam Kaidah Akuntansi Pemerintahan. Jakarta. 
Thomassen, Henry, 1990. "Capital budgeting for a state" Public Budgeting \& Finance 10 (Winter): 72-86.

Uma, Sekaran. 2006. Research Methods For Business (Metodologi Penelitian untuk Bisnis). Buku 1 dan 2, Edisi 4. Jakarta: Salemba Empat.

Sutrisno. 1984. Dasar-Dasar Ilmu Keuangan Negara. Yogyakarta: BPFE UI.

Wati, Endar Rosita. 2010. Hubungan antara Pendapatan Asli Daerah dan Dana Perimbangan dengan Belanja Modal Pemerintah Daerah Kabupaten Kudus Tahun 2003-2008. Skripsi. Semarang: Universitas Negeri Semarang.

Verbeek, Marno. 2000. "A Guide to Modern Economics." Chichester: John Wiley \& Sons.

http://www.djpkpd.go.id 